Rev. Mieczystaw Ozorowski

Cardinal Stefan Wyszynski University

DOI: $10.15290 /$ rtk.2020.19.04

iD 0000-0001-6081-0134

\title{
St. Augustine's Personal Experience of Marriage and Family and his Influence on the Theology of Marriage
}

This study presents St. Augustine's personal experiences related to marriage and family that eventually influenced his views on these topics. Augustine of Hippo is considered one of the greatest theologians of the ancient Christian world. Although he was unmarried, he was born into a Christian family and experienced what it was like to live with a woman in a quasi-married state before he converted to Catholicism. Augustine left behind a large body of writings dedicated to the topics of marriage and family. Even though these works do not constitute a coherent treaty on marriage and family, they do shed light on these issues. They also reflect the current and pressing problems that affected not only St. Augustine but also the people of his time. St. Augustine's views on marriage and family have had an immense influence on the entire Latin Church's position on these issues. In this regard, the primary source that contains a lot of biographical information is Augustine's Confessions. This study is made up of two parts. Part I describes Augustine's childhood experiences and family life. Part II describes youth and his experience living with a female concubine. This original study presents the sources of St. Augustine's views on human sexuality and his relationship with his family.

Key words: St. Augustine, marriage, family, concubinage, sexuality.

\section{Introduction}

Although Augustine of Hippo, who is considered one of the greatest theologians of the ancient Christian world, saints, and Doctors of the Church, was an unmarried man, he was born into a Christian family 
Dogmatic Theology

and experienced what it was like to live with a woman in a quasimarried state before he converted to Catholicism. This great saint left behind a large body of writings dedicated to the topics of marriage and family. Even though these works do not constitute a coherent treaty on marriage and family, they do shed light on these issues. They also reflect the current and pressing problems that affected not only St. Augustine but also those of his time. These issues undoubtedly appear in polemical writings and are Augustine's positive attempt to organize both his theological and applicable material. Based on St. Augustine's writings, he and those closest to him had personal experience with marriage and family issues. This article seeks to present St. Augustine's experiences, which influenced his views on marriage and family to some degree-views that have had an immense influence on the entire Latin Church's position on these issues. In this regard, the primary source that contains a lot of biographical information is Augustine's Confessions. In this work, he describes the first 33 years of his life and includes many details about his experiences and spiritual dilemmas. In light of this work, St. Augustine could be considered a theological psychologist. While many of his other theological works contain biographical allusions, the most pertinent to this study are those that deal with his marriage and family life.

\section{St. Augustine's Childhood Experiences of Family}

St. Augustine was born in North Africa as the son of the poor municipal official, Patricius, who had high ambitions that he passed on to his children. ${ }^{1}$ Patricius spent most of the day outside of the home socializing, and he returned to his wife, Monica, in the evening. She singlehandedly managed the household and cared for their children, with whom she had a strong emotional bond-at least this is how St. Augustine describes his relationship with his mother in his Confessions. ${ }^{2}$

St. Augustine wrote very little about his family. When describing his infancy, he relied on the stories that his family members and other children who knew and observed him told him. Augustine considered his childhood normal and his experiences, therefore, universal: "Your consolation and your mercies have raised me up, as I have heard from the parents of my flesh, for by one and in the other you fashioned me

\footnotetext{
1 A. G. Hamman, Życie codzienne w Afryce Pótnocnej w czasach św. Augustyna, Warszawa 1989, 100.

$2 \quad$ Ibid., 101.
} 
in time. I myself do not remember this. Therefore, the comfort of human milk nourished me, but neither my mother nor my nurses filled their own breasts. Rather, through them you gave me an infant's food in accordance with your law and out of the riches that you have distributed even down to the lowest level of things. You gave me want no more than you gave me, and you gave to those who nursed me the will to give what you gave them. By an orderly affection they willingly gave me what they possessed so abundantly from you. [...] Later on, I began to laugh, at first when asleep and then when awake. This has been told to me concerning myself, and I believe it, since we see other infants acting thus, although I do not remember such acts of my own." 3 It is likely that Augustine was fed by a wet nurse who remained in the family for many years as a pillar of the home. She looked after the children entrusted to her care, raised them, and over time became their confidante and helper. ${ }^{4}$

Augustine's carefree and easy childhood was typical for the time. He spent time playing with his siblings and other children his age. When he became a bishop, he looked back and judged how he behaved as a child harshly: from the beginning, his childhood was marked by sin and a tendency to [do] evil. It had nothing in common with the mythical paradise of childhood. Rather, according to Augustine, from the very beginning of his existence, man is marked with the stain of original sin. ${ }^{5}$ During Augustine's era, girls were raised more strictly than boys, and females were expected to remain virgins until they were married. Parents seemed to care less about the antics of their sons, who were expected to be wild and carefree in their youth. Augustine's father upheld this view and was proud of his offspring. Augustine's Christian mother Monica, however, thought otherwise and tried to induce her son to live according to Christian principles.

In his Confessions, Augustine barely mentions his siblings and the relationships that he had with them. He likely had one brother and two sisters. Unlike his relationship with his mother, Augustine was not very emotionally close to his siblings. In Book 10 of the Confessions, he uses only superlatives to describe his mother as a composed, dignified, pious, and wise individual. She lived a simple yet profound Christian spirituality. She had a deep faith and wanted to raise her children according to it. She had strong and vivid dreams, which she

3 Augustine, The Confessions of Saint Augustine, trans. J. K. Ryan, New York 1960, I.6, 46-47.

A. G. Hamman, Życie..., 102-103.

Ibid., 104. 
Dogmatic Theology

tried to interpret accurately and understand. In other books of the Confessions, however, Augustine does not present such an idealized image of Monica. ${ }^{6}$ For the most part, Augustine presents Monica primarily as an exceptionally possessive mother and who projected all of her feelings and ambitions on to her son. ${ }^{7}$ We know very little about Augustine's father, Patricius; Augustine writes very little about him. Patricius was a municipal official and pagan, who was baptized shortly before he died. He was a generous man but also impetuous and prone to anger. Augustine was grateful to his father for the sacrifices that he made so that Augustine could receive an education. Nevertheless, Augustine sums up his father in one sentence: "he [...] thought [...] only of vain things for me."

Augustine's parents allowed their children free rein to entertain themselves as they pleased and did not discipline them much. According to Augustine himself, this approach had dire consequences. Augustine recalls an unsettling moment that occurred at the bathhouse of his hometown where his father witnessed in his son signs that he was physically maturing and filled with youthful excitement. Patricius became intoxicated with joy and pride at the thought of his future grandchildren. Augustine's mother, however-more aware of her son's plight_admonished him not to commit adultery and, before all else, not to seduce a married woman. Augustine, however, resented his mother for not safeguarding his purity as firmly as she had felt inclined to do by giving in and permitting him to go out and have fun with his friends. ${ }^{9}$ The only remedy for this situation was for Augustine to be married, but this option was out of the question because of his studies and future career.

\section{St. Augustine's Parents: Patricius and Monica}

What did Augustine's parents' marriage look like? Based on Augustine's writings, the marriage was far from ideal. In fact, it is even possible that this family was plagued by an underlying conflict and that Augustine's parents were connected by what we would call in today's terms a toxic relationship. Patricius was unfaithful to his wife and he liked to drink, but he never physically beat Monica. Monica, on her part, patiently bore all of her husband's moods. She did not

P. Brown, Augustyn z Hippony, Warszawa 1993, 32.

7 Ibid., 22-23; H. Chadwick, Augustyn, Warszawa 2000, 103.

8 Augustine, Confessions, II.3, 69.

9

Ibid. 
resist him; instead, she waited until his anger subsided in order to peacefully mention and explain what she had done. ${ }^{10}$ Based on the social standards of the time, Augustine's parents' marriage was not typical. At that time, individuals from the same social class married each other, and a woman who married beneath her class was not respected. ${ }^{11}$ Monica likely came from a noble family and higher social class, while Patricius was an impoverished municipal official. ${ }^{12}$ Monica was clearly younger than her husband, but she was an adult when she married him. ${ }^{13}$ When it came to her own son, Monica sought to follow her own example and make the same arrangements for her son: she found him a wealthy maiden from a noble family in Milan to marry so that Monica would not be a burden on Augustine in the future and so that, through the union, Augustine would be able to advance socially. ${ }^{14}$ Monica and Patricius' union was a mixed marriage; Monica was a Christian and Patricius was a pagan who Monica was able to lead to Baptism by the end of his life and, in so doing, obtained an even greater reward from God. ${ }^{15}$

10 P. Brown, Augustyn..., 24. Augustine, Confessions, IX.9, 219: "when many wives, who had better-tempered husbands but yet bore upon their faces signs of disgraceful beatings, in the course of friendly conversation criticized their husbands' conduct, she would blame it all on their tongues. Thus she would give them serious advice in the guise of a joke. From the time, she said, they heard what are termed marriage contracts read to them, they should regard those documents as legal instruments making them slaves. Hence, being mindful of their condition, they should not rise up in pride against their lords. Women who knew what a sharp-tempered husband she had to put up with marveled that it was never reported or revealed by any sign that Patricius had beaten his wife or that they had differed with one another in a family quarrel, even for a single day. When they asked her confidentially why this was so, she told them of her policy, which I have described above. Those who acted upon it, found it to be good advice and were thankful for it; those who did not act upon it were kept down and abused."

11 R. Wiśniewski, "Św. Augustyn - św. Hieronim o konkubinacie i małżeństwach ludzi rozwiedzionych," MW 3(1994), vol. 3: 3.

12 A. Swoboda, Kobieta, żona, i matka w pismach św. Augustyna, Poznań 2012, 35. C.N. Cochrane, Chrześcijaństwo i kultura antyczna, Warszawa 1960, 379.

13 Augustine, Confessions, IX.9. G. Bardy, Święty Augustyn. Człowiek i dzieło, Warszawa 1955, 30. J. Iluk, "Chrześcijańskie małżeństwo i rodzina w rzymskiej starożytności,” in: W. Pałubicki, J. Iluk, Małżeństwo i rodzina w dawnym judaizmie i starożytnym chrześcijaństwie, Gdańsk 1995, 153-328.

14 G. Bardy, Święty Augustyn..., Warszawa 1955, 79.

$15 \quad$ J. Jundził, "Pochwały matek w literaturze czasów rzymskich - główne trendy rozwojowe," in: Rodzina w starożytnym Rzymie, ed. J. Jundził, Bydgoszcz 1993, 264-265. 
Dogmatic Theology

Augustine considered his mother the model of a strong-willed, persistent, and prudent woman who was conscious of her duties and responsibilities toward her family. ${ }^{16}$ Augustine valued his mother's foresight and prudence. ${ }^{17}$ She was admirably courageous-a virtue she demonstrated during the dangerous journeys that she made and as she approached death in a foreign country far away from her family home. ${ }^{18}$ She had reached the ancient philosophers' ideal, which could be attained only with great difficulty: she feared "neither an unfortunate accident nor death itself." ${ }^{19}$ In the face of danger, she remained calm and composed and, being a sensitive, cared for and encouraged others. ${ }^{20}$ She led a holy life and was deserving of both respect and honor. Monica's behavior reflected her love for Christ and the Church. ${ }^{21}$ She fulfilled all of her marital and family obligations in an ideal manner and in such a way that she served as an example of the ideal Roman mater familias. ${ }^{22}$ She ran the home, managed the family's material goods, and was practical in caring for her children's material and spiritual future. ${ }^{23}$ According to Augustine, a wife's job was not to fulfill her corporal desires, but rather to be the glory of her husband, meaning an example of holiness and piety. ${ }^{24}$ Without a doubt, Patricius admired Monica's virtues, since they evoked both his love and respect. ${ }^{25}$ Just as she was obedient to her husband, Monica also obediently respected all Church authorities, especially St. Ambrose,

16 A. Bober, "Rodzina kościołem domowym według św. Jana Chryzostoma," VoxP 5(1985) vol. 8-9: 193; A. Trapè, Święty Augustyn a nauki i szkolnictwo starożytne, Warszawa 1938, 26.

J. Jundził, "Pochwały matek...," 264-265.

J. Jundził, "Ideał żony i matki w Wyznaniach św. Augustyna a klasyczne wzorce rzymskie," VoxP 8(1988) vol. 15: 821.

Augustine, De ordine, I, 32; PL 32, 994. G. Bardy, Święty Augustyn..., Warszawa $1955,105$.

A. Milewska, "Monika jako ideał matki i żony przedstawiony w Wyznaniach św. Augustyna," in: Partnerka, matka, opiekunka. Status kobiety w starożytności i średniowieczu, ed. J. Jundził, Bydgoszcz 1999, 233.

1 L. Anné, "La conclusion du mariage dans la tradition et le droit de l'Eglise Latine jusqu'au VI siècle," EThL 12(1935): 522.

M. Kuryłowicz, Prawo i obyczaje w starożytnym Rzymie, Lublin 1994, 110.

Augustine, Confessions, VI.13, 23. J. Jundził, “Ideał żony i matki...,” 828.

W. Kornatowski, Spoteczno-polityczna myśl św. Augustyna, Warszawa 1965, 165.

Augustine, Confessions, IX.13,37. G. Bardy,Święty Augustyn..., 120; E. S. Lodovici, "Sessualità, matrimonio e concupiscenza in san'Agostino," in: Etica sessuale e matrimonio nel cristianesimo delle origini, ed. R. Cantalamessa, Milano 1976, 212-272. 
the Bishop of Milan. ${ }^{26}$ Needless to say, Augustine's parents' marriage and his mother's example influenced his teachings on mixed marriages and the role of Christian women in the home. ${ }^{27}$ Thanks to Monica's persistent faith, good manners, and irreproachable behavior, she won her husband over for God and became the herald of eternity and spiritual support to him. ${ }^{28}$

Monica treated her mother-in-law in a similar way. Initially, the servants tried to set Monica and her mother-in-law at odds with each other through gossip. Monica, however, showed such great care for her mother-in-law that they developed and maintain a mutual admiration for and sincere friendship with each other. ${ }^{29}$ Monica also had a talent for peacemaking and an ability to mediate such that both sides reconciled and came to an agreement. ${ }^{30}$ She showed her neighbors such goodness and kindness that others praised and recognized her for this. ${ }^{31}$ She responded with modesty, moderation, and fear to the praise that she received..$^{32}$ She was raised to behave this way from a young age. Monica was also a model of patience and meekness because she patiently bore accusations made against her and overcame them with gentleness. ${ }^{33}$ Augustine also valued his mother's tolerance, since she patiently bore his weak faith, morals, and concubinage; however, this does not mean that she condoned any of it. ${ }^{34}$

Monica detested gossip and never spread it. She also never returned to unpleasant memories, nor did she brood over or mention them. ${ }^{35}$

$26 \quad$ G. Bardy, Święty Augustyn..., 76; A. Milewska, "Monika jako ideał matki i żony," 231.

A. Swoboda, Kobieta, żona..., 45-52.

A. Milewska, "Monika jako ideał matki i żony...," 230-234.

Augustine, Confessions, IX.9, 219. E. Giannarelli, "La donna nella famiglia cristiana secondo i Padri," in: AA.VV., Matrimonio e famiglia. Testimonianze dei primi secoli, ed. M. Naldini, Fiesole 1996, 143-173.

J. Jundził, "Ideał żony i matki...," 820-822.

Augustine, Confessions, IX.9, 20. A. Milewska, “Monika jako ideał matki i żony...," 232.

Augustine, De ordine, I.11, 33, PL 32, 994; L. Anné, "La conclusion du marriage...," 522 .

Augustine, Sermo, 300, 6,6; PL 38, 1379. E. Giannarelli, "La donna nella famiglia...," 169-170.

G. Bardy, Święty Augustyn..., 38. W. Eborowicz, "Małżeństwo i rodzina w nauce i praktyce duszpasterskiej św. Augustyna," VoxP 8-9(1985): 145-146.

Augustine, Confessions, IX.9, 220: "After he became one of the faithful, she did not have to complain of what she had endured from him when he was not yet 
Dogmatic Theology

Augustine thought every women should be like his own mother, meaning exceptionally patient, prudent, sober, self-possessed, and very humble. ${ }^{36}$ He remembered his mother so warmly, and the qualities that he observed in her were undoubtedly also the qualities that he appropriated well and scrupulously implemented in his own life. ${ }^{37}$ Augustine also inherited from his parents a strong determination to achieve the goals that he set out to accomplish. ${ }^{38}$

\section{Augustine's First Love: From Concubinage to Marriage}

Augustine moved to Carthage to study rhetoric when he was 18 years old. As he himself writes: "I came to Carthage, where a caldron of shameful loves seethed and sounded about me on every side. I was not yet in love, but I was in love with love..." ${ }^{39}$ Augustine definitely experienced a crisis regarding the late stage at which he sexually matured, which he summarized in the following way: "To love and to be loved was sweet to me, and all the more if I enjoyed my loved one's body [...] I plunged headlong into love, whose captive I desired to be. But my God, my mercy, with how much gall did you sprinkle all that sweetness of mine, and how good you were to do it! For I was loved, and I had gained love's bond of joy. But in my joy I bound about with painful chains of iron, so that I might be scourged by burning rods of jealousy, and suspicion, and fear, and anger, and quarreling." ${ }^{40}$ Nothing

a believer. She was also a servant of your servants. Whosoever among them know her greatly praised you, and honored you, and loved you in her, because they recognized your presence in her heart, for the fruit of her holy life bore witness to this. She had been the wife of one husband; she repaid the duty she owed to her parents; she had governed her house piously; she had testimony for her good works."

A. Swoboda, Kobieta, żona..., 57-60.

Augustine abhorred gossip. As Possidius writes, "he had this inscription on his table: Who injures the name of an absent friend / May not at this table as guest attend. Thus he warned every guest to refrain from unnecessary and harmful tales. And when some of his most intimate fellow-bishops forgot that inscription and spoke without heeding it, Augustine on one occasion became exasperated and so sternly rebuked them as to declare that either those verses would have to be removed from the table or he would leave in the midst of the meal and retire to his chamber." Possidius, The Life of Saint Augustine, trans. H. T. Weiskotten,1919, XXII.7,http://www.tertullian.org/fathers/possidius_life_of_augustine_02_text. htm\#C22.

P. Brown, Augustyn..., 24.

Augustine, Confessions, III.1, 77.

Ibid. 
more need be added to these few words that describe the state of a young man in love.

In Carthage, Augustine met a certain unnamed young woman who was likely Christian and with whom he entered into a "second class" marriage. He cohabitated with her for the next 15 years, and they had a son, Adeodatus, whom they neither wanted nor expected. This relationship was socially acceptable and even increased the blossoming professor's prestige. ${ }^{41}$ We do not know whether Augustine himself was happy in this relationship, since he is very discrete when writing about it. In his Confessions, however, he does acknowledge that he remained emotionally attached to the woman, and his relationship with her was like a marriage in that it involved commitment and exclusivity, unlike fleeting sexual exploits. ${ }^{42}$ Augustine's separation from the woman of his life was very painful for him. Monica did not oppose Augustine's relationship with the woman in the beginning, even though, as a Christian, Monica was responsible for educating and forming her son's heart. ${ }^{43}$ She intervened in the relationship only after she found a suitable candidate for Augustine to marry: a young heiress with a considerable fortune. ${ }^{44}$ The Church was also willing to recognize the cohabitating union provided that Augustine and his concubine were faithful to each other for life.

The young Augustine had no desire to enter into a legally binding marriage, and reminded his parents about this, since they all had great ambitions and plans for him in this regard. If he did marry, then he would have had to choose a woman from Thagaste, settle down in that province as a young man, and work as a municipal officer. At least Patricius had such plans for his son and, after Patricius' death, Augustine's devout mother Monica saw to this matter. It was for this reason that she followed her son to Milan and found a rich young

$41 \quad$ P. Brown, Augustyn..., 33.

42 Augustine, Confessions VI.12,151. Augustine tried to convince his friend Alypius about this in the following way: "When I saw that he was astonished at me, I urged in my defense that there was a great difference between what he had taken quickly and furtively, which he could scarce remember, and therefore might scorn easily and without regret, and my long-continued pleasure. Moreover, if the honored name of matrimony were added to it, he ought not to wonder why I could not despise that way of life."

$43 \quad$ R. Laprat, "Le rôle de la materfamilias selon Augustin," Revue du Moyen Age latin 1(1945): 129-148. At that time, as now, it was commonly thought that people should have fun and live on the wild side in their youth. Parents, but especially fathers, were proud of the sexual exploits of their sons. 
Dogmatic Theology

candidate for him to marry. ${ }^{45} \mathrm{Up}$ until this point, no one was bothered by the fact that Augustine had a concubine because it was considered a normal and even respectable practice at that time. Moreover, Augustine's concubine was able to remain a Catholic catechumen, which is evidenced by the fact that she and Augustine named their son Adeodatus (given by God) and she raised him up as a Christian like other Christian mother's of the time did. Monika also loved her grandson dearly; she cared for and looked after him. ${ }^{46}$ Like his father, Adeodatus was very attached to Monica and was overcome with tears when she passed away. ${ }^{47}$

Augustine's nameless concubine was ultimately sent back to Africa and made a vow that she would never enter into a relationship with another man..$^{48}$ In the same paragraph where Augustine relays this information in his Confessions, he also states that he subsequently lived with a second concubine in order to satisfy his passions of the flesh. The, relationship, however, did not satisfy Augustine and only strengthened his pangs of conscience, which were stirring as his conversion process began and his longings for his first love, who was forced to leave him, remained. Augustine describes the state of his soul

Augustine, Confessions VI.13, pg.152: "Steady pressure was put upon me to get married. Soon I asked for a girl's hand, and soon she was promised to me. This was principally through my mother's activity, for she hoped that once I was married the baptism of salvation would wash me clean. Hence she rejoiced that day by day I was being prepared for it, and she noted that her prayers and your promises were being fulfilled by my faith. Then indeed, at my pleading and her own desire, each day with a mighty cry from her heart she besought you to give her in a vision some sign as to my coming marriage, but you never will to do so."

J.Łupiński, “The Concubinage of St. Augustine,” Studia Teologiczne 35(2017):268. Augustine, Confessions, IX.12, 225.

Ibid., VI.15, 153-154: "In the meantime my sins were multiplied. The woman with whom I was wont to share my bed was torn from my side as an impediment to my marriage. My heart still clung to her: it was pierced and wounded within me, and the wound drew blood from it. She returned to Africa, vowing that she would never know another man, and leaving with me our natural son. But unhappy man that I was, no imitator of a woman and impatient of delay, since it would be two years before I could have her whose hand I sought, and since I was not so much a lover of marriage as a slave to lust, I procured another woman, but not, of course, as a wife. By her my soul's disease would be fostered and brought safe, as it were, either unchanged or in a more intense form, under the convoy of continued use into the kingdom of marriage. Not yet healed within me was that wound which had been made by the cutting away of my former companion. After intense fever and pain, it festered, and it still caused me pain, although in a more chilling and desperate way." 
at this time as a deep, festering wound that would not heal. Clearly, after many years, the bishop still experienced the same emotional pain when he recalled how he had behaved in the past. ${ }^{49}$

Augustine loved his first love and respected her deeply. He, however, could neither officially nor openly express these sentiments due to the social and religious conventions of the time. In later years, he both logically and theologically determined that this relationship was not good and that it took place when he was lost and living in sin. Augustine also emphasized that God was the only one who could remove him from this swamp and wash him clean..$^{50}$ Only Augustine's fear of death and God's judgment prevented him from pursuing his passions of the flesh more ardently. Augustine found in both philosophy and the Christian faith the ultimate consolation and the stabilization of his emotions. ${ }^{51}$ Although some assert that Augustine did not truly love his concubine because, otherwise, he would have remained with her for the rest of his life,$^{52}$ he did send her coldly back to her homeland Africa without the slightest sense of guilt..$^{53}$ In this way, it is clear that, for this saintly theologian, love was neither a feeling nor emotion for another person. Rather, only God could fulfill a person's ultimate and true need for love. ${ }^{54}$ It appears, then, that Augustine initially considered the relationship between a man and woman to be a sexual bond, but then he came to see that the relationship between married Christians should be based on feelings beyond the sexual dimension. ${ }^{55}$ In his teachings, St. Augustine emphasizes that conjugal love (caritas coniugalis), which has many degrees and dimensions, is the essence of marriage. ${ }^{56}$

Augustine's conversion and acceptance of Christian doctrine completely changed his inner attitudes and priorities: "our discourse had

$49 \quad$ Ibid., VI.15(25).

50 Ibid., VI, 16.

J. Łupiński, “The Concubinage of St. Augustine," 273.

K. Power, "Sed unam tamen. Augustine and his Concubines," Augustinian Studies 23(1992): 51-57.

53 R. Doni, Święty Augustyn, Poszukiwanie prawdy, Kraków 2003, 78. This is a vague period in Augustine and Monica's interaction, and this situation is difficult to explain from the point of view of today's moral sensitivity. For both Augustine and her it was considered completely natural and obvious. Augustine, Soliloquia, 1,10. R. Doni, Święty Augustyn..., 79. Augustine, Confessions, IX.10.

A. Swoboda, Kobieta, ̇̇ona..., 91-102; A. Swoboda, "Owoce sakramentu małżeństwa. Refleksja teologiczno-pastoralna św. Augustyna," in: Problemy duszpasterskie starożytnego Kościoła, Lublin 2009, 113-146. 
been brought to the point that the highest delight of fleshly senses, in the brightest corporeal light, when set against the sweetness of [eternal] life seemed unworthy not merely of comparison with it, but even of remembrance." ${ }^{57} \mathrm{He}$ also became liberated from earthly ambitions and the desires of the flesh. ${ }^{58}$ This came, however, at the cost of maintaining a definite distance from women. As Bishop Possidius, Augustine's biographer, confirms, after Augustine's conversion, no woman-not even his sister or his brother's daughters-lived with him. Augustine also ensured that he never spoke with a woman alone and that a witness was always in order to avoid suspicion. ${ }^{59}$

In his work Of the Good of Marriage, Augustine mentions indirectly the example of his relationship with the nameless concubine and confesses that he would not call any woman adulteress who, having left her lover to whom she had been faithful and even bore children, had resolved to never marry or have sexual relations with another man. This is precisely what happened to Augustine's concubine,${ }^{60}$ with whom he had lived for 15 years and bore an unwanted child whom he later loved. He wrote the following on this topic in his Confessions: "In those years I had a woman companion, not joined to me in what is named lawful wedlock, but one whom my wandering passion, empty of prudence, had picked up. But I had this one only, and moreover I was faithful to her bed. With her I learned at first hand how great a distance lies between the restraint of a conjugal covenant, mutually made for the sake of begetting offspring, and the bargain of a lustful love, where a child is born against our will, although once born he forces himself upon our love." ${ }^{11}$ After his conversion, Augustine encouraged his readers to convert and abandon their concubines because such a relationship is sinful, and he asserted that such converts could receive the sacrament of baptism. ${ }^{62}$

57

Augustine, Confessions, IX.10, 221.

Ibid., IX.1: "Now as my mind free from the gnawing cares of favor-seeking, of striving for gain, of wallowing in the mire, and of scratching lust's itchy sore." X.37: With regard to fleshly pleasures and curiosity to know idle things, I perceive to what extent I have attained the power of restraining my mind when I am gree of such things, either voluntarily or because they are not present. Then I ask myself whether not having them is more annoying or less annoying to me.

Possidius, The Life of St Augustine..., 26:1-3.

J. Jundził, "Partnerstwo w małżeństwie rzymskim-typy i modele,” Miscellanea Antropologica et Sociologica 2(1993): 89-96.

Augustine, Confessions, IV.2, 94.

A. Swoboda, Kobieta, żona..., 220. 
After being baptized and becoming the Bishop of Hippo, Augustine spoke decisively against concubinage and was fundamentally opposed to it. ${ }^{63}$ He believed that the reason people entered into such a relationship was because of unbridled passion and imprudent lust, to which he himself personally admitted when recalling the relationships of his youth.$^{64}$ In his letters and homilies, Augustine also condemned concubinage and called it adulterous. He permitted cohabitation under certain conditions: as a lifelong union that is open to children. ${ }^{65}$ Augustine considered concubinage like a blood relationship (cognatio naturalis), or like natural monogamous marriage, only second-class. ${ }^{66}$ Augustine's own experience with cohabitation is echoed in his teachings. He also saw concubinage as a means to prevent promiscuity. In this way, a man binds himself to a lasting and faithful sexual relationship with only one woman. Although this type of relationship was not included in Church law, it was permitted and respected by a large part of society. ${ }^{67}$ Augustine nevertheless makes a clear distinction between marriage and concubinage. Marriage is for the purpose of producing offspring, while concubinage is for the purpose of satisfying the passions. ${ }^{68}$

Augustine's relationship with the unnamed concubine was firmly imprinted in his memory and subconsciousness, and it comes to the fore impulsively through his impressionistic dreams ${ }^{69}$ He laments before both God and his readers the fact that he is unable to control

Ibid., 214-220.

Augustine, Confessions, VI.15, 25. N. Blázquez, "Feminismo agustiniano," Augustinus 27(1982): 3-53.

Augustine, De bono coniugali, 4:4, 5:5. R. Wiśniewski, "Św. Augustyn - św. Hieronim o konkubinacie...," 5 .

B. Łapicki, Prawo rzymskie, Warszawa 1948, 253.

A. Trapè, Święty Augustyn a nauki..., Warszawa 1938, 41. A.G. Hamman, Życie codzienne..., 87-88.

Augustine, Confessions, IV.2:2. H. Crouzel, "La concupiscence charnelle dans le mariage selon saint Augustin," BLE 88(1987): 287-308.

Augustine, Confessions, X.30, 256: "You have commanded me to abstain from concubinage, and in place of marriage itself, which you permit, you have counseled something better. Since you granted this to me, it has been fulfilled even before I became a dispenser of your sacrament. Yet in my memory, of which I have said many things, there still live images of such things as my former habits implanted there. When I am awake, they assail me but lacking in strength; in sleep they assail me not only so as to arouse pleasures, but even consent and something very like the deed itself. So great a power have these deep images over my soul and my flesh that these false visions persuade me when asleep to do what true sights cannot persuade me to when awake. At such a time, am I not myself, O Lord, my God? Yet so great a difference is there between myself 
Dogmatic Theology

these dreams and he does not know what to do about them. For one cannot exercise rational discipline in one's dreams the way one does in reality. Augustine realized, however, that they were only dreams during which one does not $\sin$ and for which one is not guilty. $\mathrm{He}$ is ashamed, however, and humiliated by his dreams and, therefore, asks God to silence his passions even in his dreams-the dreams of a mature man. ${ }^{70}$

It was not so much Augustine's moral scruples that led to the breakdown of his relationship with his concubine, but rather his unbridled ambition and the fact that he was to enter into marriage with a young Catholic heiress, thanks to whom he would be able to attain a high state office. Unfortunately, the candidate for marriage was a young 10 -year-old girl, and Augustine would have to wait two more years before he could legally marry her. ${ }^{71} \mathrm{He}$ was willing to sacrifice the emotional bonds that served to satisfy his passions in order to marry. In this situation, he was not motivated by any particular spiritual or intellectual values, but rather likely tyrannized by his mother. ${ }^{72}$

What Augustine sought in a legal spouse was nothing extraordinary. He wanted his wife to be beautiful but modest and polite, educated or able to learn. He also wanted her to have a dowry and to not be a burden on him. Certainly, the young candidate met all of these criteria, but the real model of a virtuous wife was Augustine's own mother, Monica. ${ }^{73}$ Augustine valued marital chastity very highly and frequently insisted that both husbands and wives respect it equally. Augustine's mother's example was impeccable in this regard; his father, however, and the males in his family behaved otherwise. ${ }^{74}$

and that same self of mine within the moment when I pass from waking to sleep or return hither from sleep!"

Ibid., X.30, 257: Lord, more and more will you increase in me your gifts, so that my soul, freed from the clinging mire of concupiscence, may follow me to you, so that it may not rebel against itself, so that even in sleep it will not commit those base corrupting deeds, brought on through corporeal images even to bodily pollution, so that it will not even consent to them. For that such a thing may give no pleasure at all, or so little as may be curbed easily even in the chaste affection of one asleep, not only in this life but even at my present age-this is no great thing to the Almighty, for you are 'able to do more than we desire and understand."”

R. Doni, Święty Augustyn..., Kraków 2003, 77.

P. Brown, Augustyn..., 57.

A. Swoboda, Kobieta, żona..., 53.

Ibid., 54-56. A. Milewska, "Monika jako ideał...," 233. A.G. Hamman, Życie codzienne..., 99 . 
After observing family customs and studying Sacred Scripture, St. Augustine frequently emphasized the equality between men and women, at least according to divine law. While Augustine did not question civil law, he demanded more from Christians. ${ }^{75} \mathrm{He}$ upheld that equality of spouses should apply to many issues such as the opportunity to accuse the other in court for a variety of reasons, but particularly for infidelity and divorce.$^{76}$ Augustine's ideal of marriage is quite conservative. The wife should be obedient to her husband and treat him as her lord even when she is better than him both morally and in other ways. ${ }^{77}$ Augustine witnessed this example not only in his parents' relationship but also in many other Christian marriages. ${ }^{78} \mathrm{~A}$ wife's obedience to her husband is a sign of obedience to God himself. The Church's submission and obedience to Christ at as the Head of the Church is the example that wives should follow. The obedience of wives should not be blind or slavish. Rather, wives and husbands are equally called to establish the family social unit and be responsible for the marriage and the family. ${ }^{79}$ Augustine's mother, Monica, is an immutable example of this kind of obedience and responsibility; for, she not only advised her husband and led him to the catechumenate and baptism, she also instructed other married women how to behave. ${ }^{80}$

\section{Conclusion}

St. Augustine remains the most well known theologian of the ancient Latin-speaking world. He left behind an abundance of writings that have continued to inspire generations of theologians and pastors. His theological reflections are based not only on his study of Sacred Scripture but also influenced by his pastoral experience. Some of the most important topics that Augustine addresses in his teachings are marriage and family. This article presents the influence that St. Augustine's own experience of family had on his writings. His mother

75 A. Swoboda, Kobieta, żona..., 68-74.

76 G. Careti,Divortio, nouve nozze e penitenza nella Chiesa primitiva, Bologna 1977, 239. A. Eckmann, "Wielkość i godność kobiety według świętego Augustyna," in: Kobieta w starożytności chrześcijańskiej, SACH 14(1999), 32-42.

$77 \quad$ A. Swoboda, Kobieta, żona..., 75.

78 J. Jundził, "Ideał żony i matki w Wyznaniach św. Augustyna a klasyczne wzorce rzymskie," VoxP 8(1988), vol. 15: 817-822.

A. Eckmann, "Wielkość i godność kobiety...," 182.

Augustine, Confessions, IX.9, 19. A. G. Hamman, Życie codzienne..., 96. 
Dogmatic Theology

and father's example as well as his serious relationship with a woman during his youth definitely influenced his views.

\section{Bibliography:}

1. Anné, L. "La conclusion du mariage dans la tradition et le droit de l'Eglise Latine jusqu'au VI siècle." EThL 12(1935): 513-550.

2. Augustine. The Confessions of Saint Augustine, Translated by J. K. Ryan. New York 1960.

3. Bardy, G. Święty Augustyn. Człowiek i dzieło. Warszawa 1955.

4. Blázquez, N. "Feminismo agustiniano." Augustinus 27(1982): 3-53.

5. Bober, A. Rodzina Kościołem domowym wedtug św. Jana Chryzostoma. VoxP 5(1985). Volume 8-9, 193-200.

6. Brown, P. Augustyn z Hippony. Warszawa 1993.

7. Careti, G. Divortio, nouve nozze e penitenza nella Chiesa primitiva. Bologna 1977.

8. Chadwick, H. Augustyn. Warszawa 2000.

9. Cochrane, C. N. Chrześcijaństwo i kultura antyczna. Warszawa 1960.

10. Crouzel H., "La concupiscence charnelle dans le mariage selon saint Augustin." BLE 88(1987): 287-308.

11. Doni, R. Święty Augustyn, Poszukiwanie prawdy. Kraków 2003.

12. Eborowicz, W. "Małżeństwo i rodzina w nauce i praktyce duszpasterskiej św. Augustyna." VoxP 8-9(1985): 145-146.

13. Eckmann, A. "Wielkość i godność kobiety według świętego Augustyna." In: Kobieta w starożytności chrześcijańskiej, SACH 14(1999), 32-42.

14. Giannarelli, E. "La donna nella famiglia cristiana secondo i Padri." In: AA.VV., Matrimonio e famiglia. Testimonianze dei primi secoli. Edited by M. Naldini. Fiesole 1996, 143-173.

15. Hamman, A. G. Życie codzienne $w$ Afryce Pótnocnej w czasach św. Augustyna. Warszawa 1989.

16. Iluk, J. "Chrześcijańskie małżeństwo i rodzina w rzymskiej starożytności." In: W. Pałubicki, J. Iluk. Małżeństwo i rodzina $w$ dawnym judaizmie i starożytnym chrześcijaństwie. Gdańsk 1995, 153-328.

17. Jundził, J. "Ideał żony i matki w Wyznaniach św. Augustyna a klasyczne wzorce rzymskie.” VoxP 8(1988). Volume 15: 817-822.

18. Jundził, J. "Partnerstwo w małżeństwie rzymskim - typy i modele." Miscellanea Antropologica et Sociologica 2(1993): 89-96.

19. Jundził, J. "Pochwały matek w literaturze czasów rzymskich - główne trendy rozwojowe." In: Rodzina w starożytnym Rzymie. Bydgoszcz 1993.

20. Kornatowski, W. Społeczno-polityczna myśl św. Augustyna. Warszawa 1965.

21. Kuryłowicz, M. Prawo i obyczaje w starożytnym Rzymie. Lublin 1994.

22. Laprat, R. "Le rôle de la materfamilias selon Augustin." Revue du Moyen Age latin 1(1945): 129-148.

23. Lodovici, E. S. "Sessualità, matrimonio e concupiscenza in san'Agostino". In: Etica sessuale e matrimonio nel cristianesimo delle origini. Edited by R. Cantalamessa. Milano 1976, 212-272. 
24. Łupiński, J. "The Concubinage of st. Augustine." Studia Teologiczne 35(2017): 261-279.

25. Milewska A., "Monika jako ideał matki i żony przedstawiony w Wyznaniach św. Augustyna." In: Partnerka, matka, opiekunka. Status kobiety w starożytności i średniowieczu. Edited by J. Jundził. Bydgoszcz 1999, Dogmatic 230-234.

26. Possidius. The Life of St. Augustine. Translated by H. T. Weiskotten. http:// www.tertullian.org/fathers/possidius_life_of_augustine_02_text.htm\#C22.

27. Power, K. "Sed unam tamen. Augustine and his Concubines." Augustinian Studies 23(1992): 49-76.

28. Swoboda, A. Kobieta, żona, i matka w pismach św. Augustyna. Poznań 2012.

29. Swoboda, A. "Owoce sakramentu małżeństwa. Refleksja teologicznopastoralna św. Augustyna." In: Problemy duszpasterskie starożytnego Kościoła. Lublin 2009, 113-146.

30. Trapè, A. Święty Augustyn a nauki i szkolnictwo starożytne. Warszawa 1938.

31. Wiśniewski, R. "Św. Augustyn - św. Hieronim o konkubinacie i małżeństwach ludzi rozwiedzionych." MW 3(1994). Volume 3: 3-7. 